\title{
Toxicological aspects of increased use of surface and hand disinfectants in Croatia during the COVID-19 pandemic: a preliminary report
}

\author{
Željka Babić, Rajka Turk, and Jelena Macan \\ Institute for Medical Research and Occupational Health, Croatian Poison Control Centre, Occupational Health and \\ Environmental Medicine Unit, Zagreb, Croatia
}

[Received in July 2020; Similarity Check in July 2020; Accepted in August 2020]

\begin{abstract}
All COVID-19 prevention strategies include regular use of surface disinfectants and hand sanitisers. As these measures took hold in Croatia, the Croatian Poison Control Centre started receiving phone calls from the general public and healthcare workers, which prompted us to investigate whether the risk of suspected/symptomatic poisonings with disinfectants and sanitisers really increased. To that end we compared their frequency and characteristics in the first half of 2019 and 2020. Cases of exposures to disinfectants doubled in the first half of 2020 (41 vs 21 cases in 2019), and exposure to sanitisers increased about nine times (46 vs 5 cases in 2019). In 2020, the most common ingredients of disinfectants and sanitisers involved in poisoning incidents were hypochlorite/glutaraldehyde, and ethanol/isopropyl alcohol, respectively. Exposures to disinfectants were recorded mostly in adults (56\%) as accidental (78 \%) through ingestion or inhalation ( $86 \%$ ). Fortunately, most callers were asymptomatic (people called for advice because they were concerned), but nearly half reported mild gastrointestinal or respiratory irritation, and in one case severe symptoms were reported (gastrointestinal corrosive injury). Reports of exposure to hand sanitisers highlighted preschool children as the most vulnerable group. Accidental exposure through ingestion dominated, but, again, only mild symptoms (gastrointestinal or eye irritation) developed in one third of the cases. These preliminary findings, however limited, confirm that increased availability and use of disinfectants and sanitisers significantly increased the risk of poisoning, particularly in preschool children through accidental ingestion of hand sanitisers. We therefore believe that epidemiological recommendations for COVID-19 prevention should include warnings informing the general public of the risks of poisoning with surface and hand disinfectants in particular.
\end{abstract}

KEY WORDS: corrosive injury; ethanol; hand sanitisers; hypochlorite; preschool children

Prevention against COVID-19 infection in households includes regular use of biocidal agents, more specifically surface disinfectants and hand sanitisers $(1,2)$, and regulatory bodies are under increasing pressure to authorise ever more disinfecting and sanitising products. In the first five months of 2020, the Croatian Ministry of Health authorised marketing of 119 hand and 79 surface disinfectants labelled as biocidal products for human hygiene (Product Type 1, PT1) and surface disinfection (PT2) according to the Regulation (EU) 528/2012 (3) as opposed to only 14 hand and 71 surface disinfectants approved in 2019 (direct communication with the Ministry). This raises concern that their increased availability and (mis)use can have adverse health effects.

The aim of our preliminary study was to establish if this concern is real. To that effect we relied on actual reports to our Croatian Poison Control Centre (CPCC), which provides consultation services to physicians and general

Corresponding author: Jelena Macan, Institute for Medical Research and Occupational Health, Croatian Poison Control Centre, Occupational Health and Environmental Medicine Unit, Ksaverska cesta 2, 10000 Zagreb, Croatia, E-mail:jmacan@imi.hr public who report any kind of exposure to toxic agents and suspected or symptomatic poisoning.

\section{METHODS}

We analysed all records of telephone consultations at the CPCC related to suspected and symptomatic poisonings with disinfectants and sanitisers and compared their frequency in the first six months of 2019 and 2020. For products whose trade name was reported, we consulted the Material Safety Data Sheet (MSDS) registry of the Croatian Institute for Public Health (4) to get more information about biocidal product type (PT), ingredients, and labelling.

Private patient information was partly protected by the fact that calls to CPCC are generally anonymous. To protect it further, we present group averages only and do not describe individual cases.

\section{Statistical analysis}

Data were analysed with descriptive statistics and chisquared and Fisher's exact test to compare records from 
2019 and 2020. Associations were considered statistically significant if $\mathrm{P}$ was $<0.05$. All analyses were run with the RStudio statistical software (Boston, MA, USA) (5).

\section{RESULTS AND DISCUSSION}

Only a small percentage of consultations in both years was related to exposure to disinfectants and hand sanitisers. In the first half of 2019 , they made only $1.8 \%(\mathrm{~N}=21)$ and $0.4 \%(\mathrm{~N}=5)$ for disinfectants and hand sanitisers, respectively, of the total of 1165 consultations. Even though the number of all consultations - 1206 in total - did not rise much over the first half of 2020, the percentage of those involving disinfectants and hand sanitisers soared to $3.4 \%$ $(\mathrm{N}=41)$ and $3.8 \%$ (46) (Figure 1). Differences are significant: $\mathrm{P}=0.015$ for disinfectants and as high as $\mathrm{P}<0.001$ for hand sanitisers.

Regarding the type of products, trade names of disinfectants were provided in $27(66 \%)$ cases in 2020 . Our MSDS search showed that 18 of these were labelled as corrosives that may cause severe damage to skin, eyes, or mucous membranes through contact, ingestion, or inhalation. More importantly, only 14 were authorised for use by the general public. The most common active ingredients in these products were hypochlorites in concentrations $<5 \%$. The remaining 13 of the 27 known disinfectants were various products for use in healthcare facilities, veterinary hygiene, food industry, catering services, etc. The most common active ingredients in these products were strong corrosives used in much higher concentrations: quaternary ammonium compounds (concentration $10 \%$ ), glutaraldehyde (concentration $5-10 \%$ ), and benzalconium chloride (concentration 10 $15 \%)$.

As for hand sanitisers, trade names were provided in 20 cases in 2020. The most common active ingredients in them, according to the MSDS, were ethanol (concentration

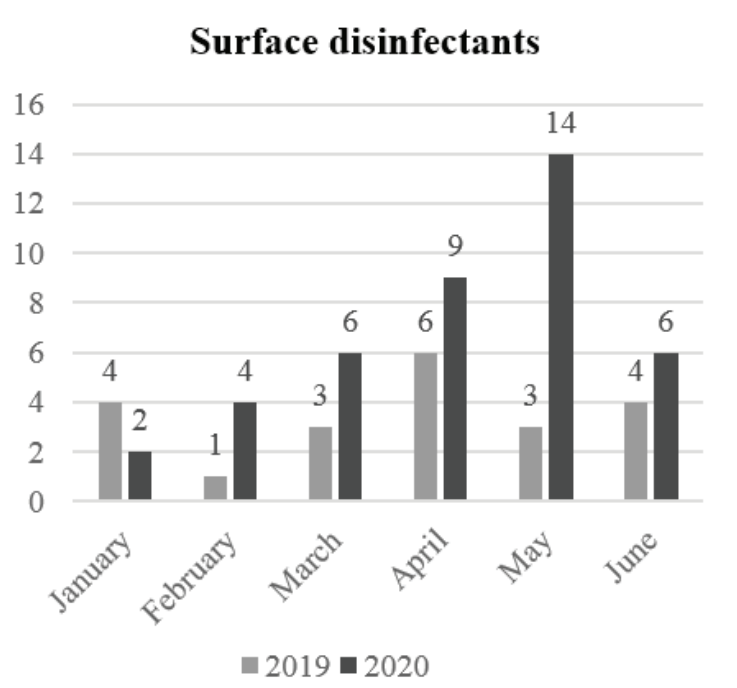

70-80\%), isopropyl alcohol (concentration 10-100\%), and chlorhexidine (concentration $<5 \%$ ), which are all skin, eye, and mucous membrane irritants with a potential for systemic alcohol intoxication.

In 2020, we identified one important difference in the pattern of exposure between disinfectants and hand sanitisers (Table 1). Namely, exposure to disinfectants was most common in adults whereas exposure to hand sanitisers was most common in preschool children, which suggests that hand sanitisers should not be as readily available to children as they are at the moment. Fortunately, most callers reported no or mild symptoms (gastrointestinal, respiratory, or eye irritation) but were worried that these might develop later on. The only case of severe accidental poisoning (corrosive injuries of gastrointestinal tract) was reported for an adult who drank a disinfectant brought home from the workplace.

Patterns of exposure to disinfectants and hand sanitisers did not differ significantly between 2019 and 2020 (data not shown), save for an increase in occupational exposure to disinfectants from none in 2019 to 5 in 2020.

Our findings are similar to a recent US report (6). Even though such exposures rarely involve severe (lifethreatening) symptoms and clinical outcomes (7), cases of ethanol poisoning with hand sanitisers in children call for alert $(8,9)$. This may be related to poor regulatory control and omission of warning on product labels. A case in point is methanol poisoning with alcohol-based hand sanitisers (accidental or intentional) reported by Chan and Chan (10). Fortunately, methanol is banned from biocidal products in Croatia, and we did not record any such cases. The issue, however, remains that labels should be more clear and warn against excessive or improper use of these products. With that in mind, CPCC has published guidelines for the general public with basic advice for prevention of toxic effects caused by disinfectants and hand sanitisers in households (11). Similar warnings should make part of other, mostly epidemiological, recommendations for COVID-19

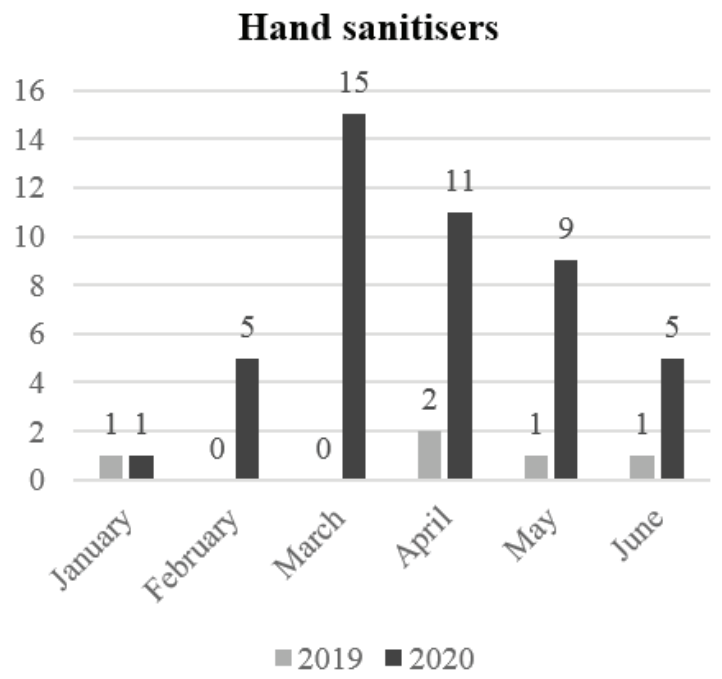

Figure 1 Number of cases involving surface disinfectants and hand sanitisers reported to CPCC in the first half of 2019 and 2020 
Table 1 Differences in the pattern of exposure to surface disinfectants and hand sanitisers (data reported to CPCC from 1 January to 30 June 2020)

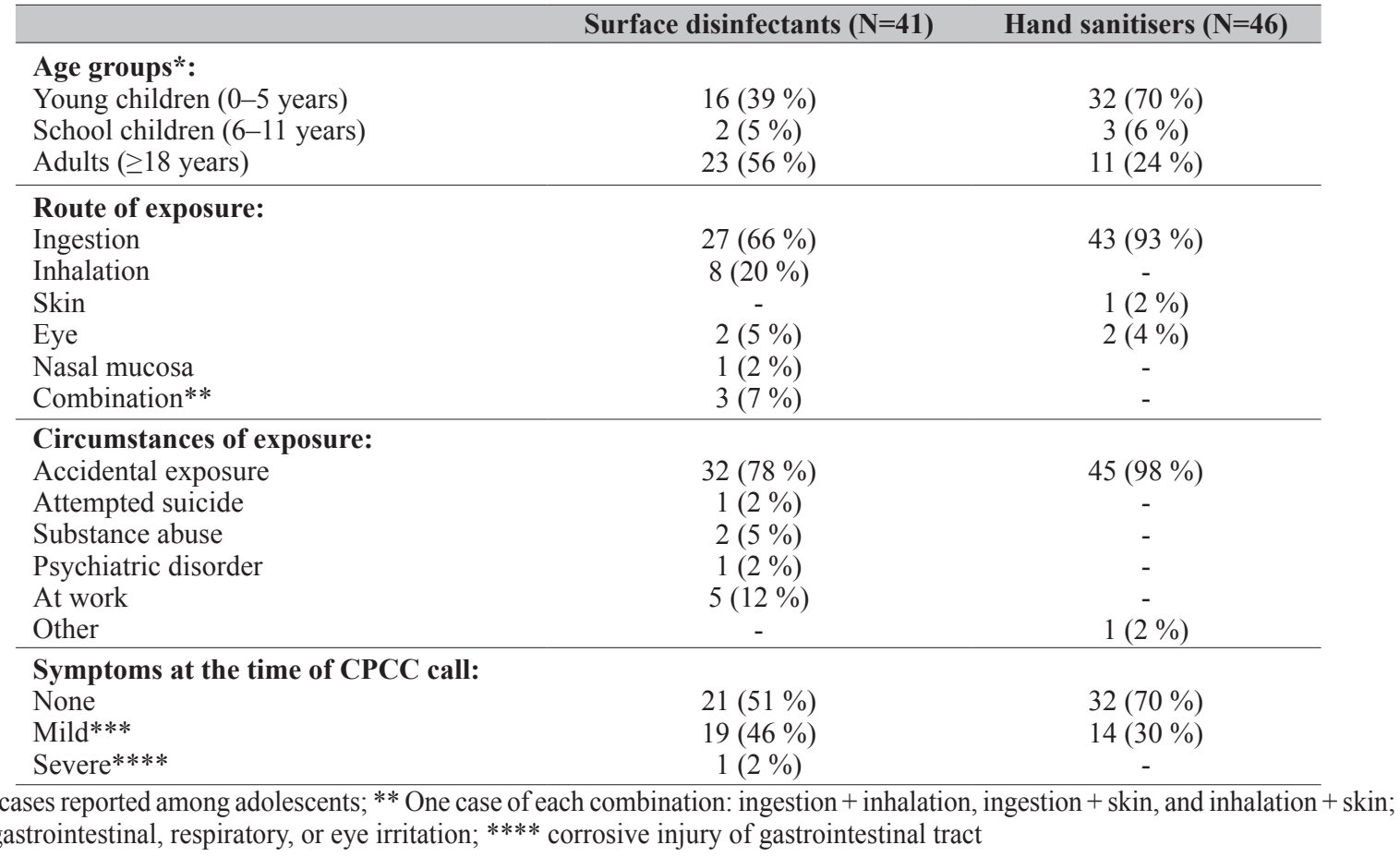

prevention. Furthermore, labelling, packaging, and availability of biocidal products should be controlled better to improve safe use, especially at home.

Even though our sample was small and study design limited, this preliminary report clearly shows that the risk of poisoning with disinfection products has increased and that the threat is real. It has also raised other issues (preschool children as vulnerable population, circumstances and severity of poisoning, implementation and effects of preventive measures, including child-resistant containers), which should be addressed by a broad epidemiological study.

\section{REFERENCES}

1. World health Organization. Cleaning and disinfection of environmental surfaces in the context of COVID-19. Interim guidance, 2020 [displayed 9 July 2020]. Available at https://www. who.int/publications/i/item/cleaning-and-disinfection-ofenvironmental-surfaces-inthe-context-of-covid-19

2. Centers for Disease Control and Prevention. Cleaning and Disinfection for Households. Interim Recommendations for U.S Households with Suspected or Confirmed Coronavirus Disease 2019 (COVID-19), 2020 [displayed 9 July 2020]. Available at https://www.cdc.gov/coronavirus/2019-ncov/prevent-getting-sick/ cleaning-disinfection.html

3. Regulation (EU) No 528/2012 of the European Parliament and of the Council of 22 May 2012 concerning the making available on the market and use of biocidal products [displayed 9 July 2020]. Available at https://eur-lex.europa.eu/legal-content/EN/TXT/ PDF/?uri=CELEX: 32012R0528\&from=EN
4. Služba za toksikologiju Hrvatskog zavoda za javno zdravstvo. Registar sigurnosno-tehničkih listova, deklaracija i uputa [Database of Safety Data Sheets, in Croatian] [displayed 7 April 2020]. Available at http://37.48.233.226/registar-sigurnosno-tehnickihlistova-deklaracija-i-uputa

5. R Studio Team. Integrated Development for R. RStudio, 2019 [displayed 9 July 2020]. Available at http://www.rstudio.com/

6. Chang A, Schnall AH, Law R, Bronstein AC, Marraffa JM, Spiller HA, Hays HL, Funk AR, Mercurio-Zappala M, Calello DP, Aleguas A, Borys DJ, Boehmer T, Svendsen E. Cleaning and disinfectant chemical exposures and temporal associations with COVID-19National Poison Data System, United States, January 1, 2020-March 31, 2020. MMWR Morb Mortal Wkly Rep 2020;69:496-8.

7. Santos C, Kieszak S, Wang A, Law R, Schier J, WolkinA. Reported adverse health effects in children from ingestion of alcohol-based hand sanitizers - United States, 2011-2014. MMWR Morb Mortal Wkly Rep 2017;66:223-6.

8. Rayar P, Ratnapalan S. Pediatric ingestions of house hold products containing ethanol: a review. Clin Pediatr (Phila) 2013;52:203-9. doi: 10.1177/0009922812470970

9. Hertzog JH, Radwick A. Acute alcohol intoxication in a child following ingestion of an ethyl-alcohol-based hand sanitizer. Int J Clin Pharmacol Ther 2015;53:557-60. doi: 10.5414/CP202362

10. Chan APL, Chan TYK. Methanol as an unlisted ingredient in supposedly alcohol-based hand rub can pose serious health risk. Int J Environ Res Pub Health 2018;15:1440. doi: 10.3390/ ijerph15071440

11. Babić Ž, Macan J, Turk R. Toksikološke preporuke za primjenu antiseptika idezinficijensa tijekom borbe protiv širenja koronavirusa [Toxicological guidelines for the use of antiseptics and disinfectants to fight coronavirus spread, in Croatian] [displayed 30 July 2020]. Available at: https://www.imi.hr/hr/2020/24/03/toksikoloskepreporuke-za-primjenu-antiseptika-i-dezinficijensa-tijekom-borbeprotiv-sirenja-koronavirusa/ 
Toksikološki aspekti povećane uporabe dezinficijensa u Hrvatskoj za vrijeme COVID-19 pandemije: preliminarno istraživanje

Preventivne strategije za COVID-19 infekciju u kućanstvima, javnim i radnim prostorima uključuju redovitu uporabu biocidnih proizvoda - dezinficijensa za površine i za kožu šaka. Analizirali smo pozive zaprimljene u hrvatskom Centru za kontrolu otrovanja vezane uz sumnju na otrovanja, odnosno simptomatska otrovanja dezinficijensima. Cilj studije bio je usporediti broj i karakteristike tih poziva, zaprimljenih u prvih šest mjeseci u 2019. i u 2020. godini, kako bi se procijenio utjecaj COVID-19 pandemije. Broj slučajeva izloženosti dezinficijensima za površine udvostručio se u prvih šest mjeseci u 2020. u odnosu na 2019. godinu (41 vs 21 slučaj), a izloženost dezinficijensima za šake povećala se oko devet puta (46 vs 5 slučajeva). U 2020. godini najčešći sastojci dezinficijensa za površine i šake uključeni u slučajeve otrovanja bili su hipoklorit/glutaraldehid, odnosno etanol/izopropilni alkohol. Izloženost dezinficijensima za površine zabilježena je najčešće u odraslih osoba (56\%), kao slučajna izloženost (78 \%) ingestijom ili inhalacijom (86\%), s blagim simptomima (iritacija gastrointestinalnoga ili respiratornoga sustava) u $46 \%$ i teškim otrovanjem (korozivna ozljeda gastrointestinalnoga sustava) u samo jednom slučaju. Izloženost dezinficijensima za šake zabilježena je najčešće u predškolske djece (70 \%), kao slučajna izloženost (98 \%) ingestijom (93\%), s razvojem blagih simptoma (iritacija gastrointestinalnoga sustava ili oka) u samo $30 \%$ slučajeva. Zaključno, povećana dostupnost i uporaba dezinficijensa za površine i šake u Hrvatskoj tijekom COVID-19 pandemije dovela je do značajnog povećanja broja potencijalno toksičnih izloženosti, naročito slučajnih ingestija dezinficijensa za šake u predškolske djece. Osnovne mjere prevencije toksičnih učinaka biocida trebaju biti uključene u epidemiološke preporuke za prevenciju COVID-19 infekcije.

KLJUČNE RIJEČI: korozivna ozljeda; etanol; dezinficijensi; hipoklorit; predškolska djeca 